المقدمة الموسيقية لمسلسل بين القصرين لجمال سلامة والاستفادة منه في استلهام تمارين

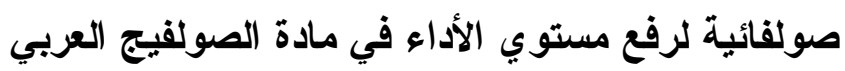

أ.م. دـ / أسامه سمير عياد"(")

\title{
مقامة البحث
}

تعد المسلسلات من أكثر الفنون جماهيرية ومن أقواها تأثير اً علي الناس، وبالتالي فهي أكثر انتشار اً وأسهل تتاولاً من سائر الفنون الأخري.

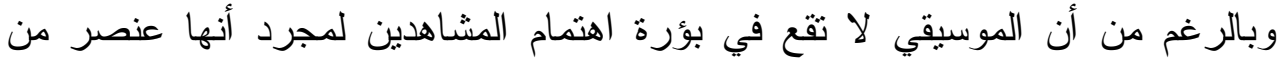

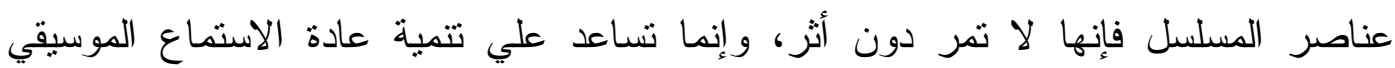
وتطويرها والتوسع في امكانية التصور الموسيقي للمواقف الدرامية، وتعتبر مصر رائدة في لإني انتاج المسلسلات منذ نشأة التليفزيون في بداية الستينات من القرن العشرين مما ساعد علي ولئي

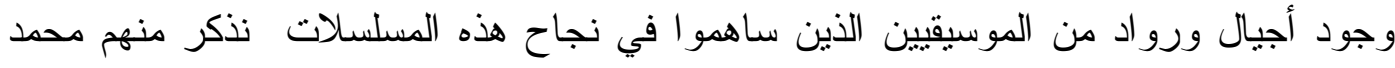
الموجي، ابر اهيم رجب، هاني مهني، جمال سلامة، عمار الثريعي، وميشيل المصري وغير هم من الملحنين الذين أثروا هذا المجال.

فبسبب تعدد حلقات المسلسل التليفزيوني فيما بين خمسة عشر حلقة إلي ثلاثين حلقة، وتكرار إذاعة تتر البداية والنهاية فإنه يساعد المشاهدين علي معايشة الإحساس بأحداثه، ومختلف المو اقف الدرامية له، ومن هنا رأي الباحث أنه يمكن الاستفادة من موسيقي تتر أحد المسلسلات المصرية وهو مسلسل بين القصرين للملحن جمال سلامة لاستلاهام تمارين صولفائية

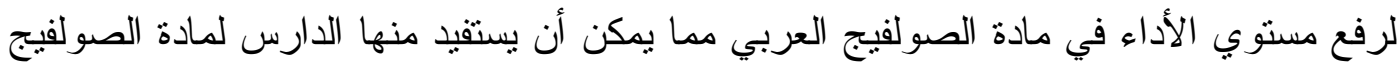

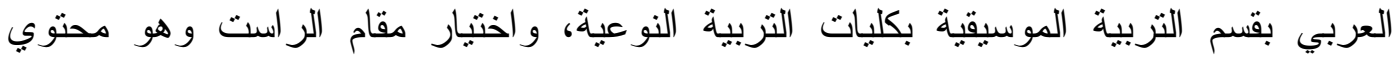
المقرر الدراسي بمادة الصولفيج العربي للفرقة الأولي. مشكلة البحث

بالرغم من أن جمال سلامة يتميز بتعدد الانتاج الفني للأعمال الغنائية والموسيقي

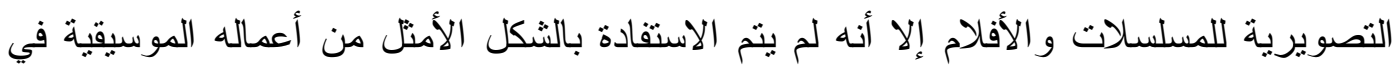
تدريس مادة الصولفيج العربي لطالب الفرقة الأولي بقسم التربية الموسيقية بكليات النربية 
النوعية، ولهذا رأي الباحث أنه يمكن استلهام تدرييات صولفائية من أحد ألحان جمال سلامة

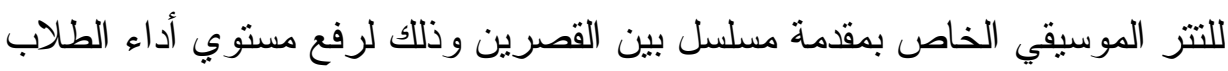
هدف البحث

يهذف البحث الحالي إلي الاستفادة من المقدمة الموسيقية لتتر مسلسل بين القصرين لجمال سلامة في التذريس لمادة الصولفيج العربي وذللك من خلال وضع ندريبات صولفائية

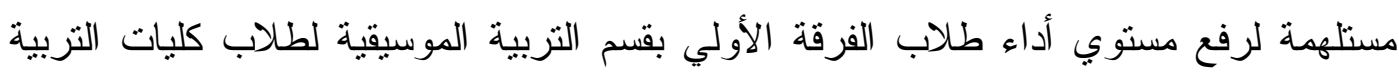

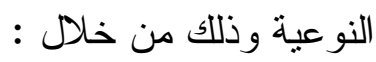

1 - غناء جمل لحنية من موسيقي أحد ألحان جمال سلامة وهو لحن التتر الموسيقي الخاص

بقدمة مسلسل بين القصرين )

r- استلاهام تدريبات صولفائية من بعض الجمل اللحنية من التتر الموسيقي الخاص بمقدمة

مسلسل بين القصرين

فرض البحث

يفترض الباحث أنه عن طريق التذريبات الصولفائية المستلهمة من المقدمة الموسيقية لتتر

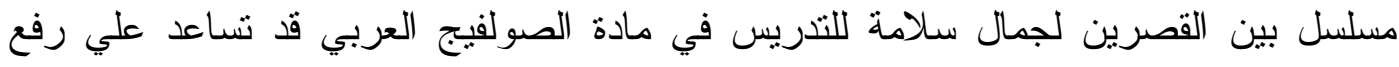
مستوي أداء طلاب الفرقة الأولي بقسم التربية الموسيقية لطلاب كليات التربية النوعية. أهمية البحث منثي أداء

1-ربط مادة الصولفيج العربي بألحان مشهورة تيسر علي الطلاب دراستهم للمادة في بادئ

$$
\text { در استهم }
$$

r- الإحساس بالمقام الموسيقي وأداء نغماته في إطار من الدقة و المتعة.

$$
\text { اجراءات البحث البحث }
$$

المقدمة الموسيقية لتتر مسلسل بين القصرين لجمال سلامة.

$$
\text { أدوات البحث }
$$

$$
\text { C.D - مدونات - كتب - مسر اجع }
$$




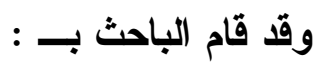

1- عرض المقدمة لتتر مسلسل بين القصرين ومحاولة أدائها صولفائياً.

r-عرض التدريبات المستلهمة من المقدمة الموسيقية لتتر المسلسل بجميع الانتقالات

$$
\text { المقامية وتحو يلاتها و أدائها صولفائياً }
$$

حدود البحث

تدريبات صولفائية مبتكرة تتاسب طلاب الفرقة الأولي بقسم التربية الموسيقية لطلاب كليات

$$
\text { النزبية النو عية. }
$$

$$
\text { مصطلحات البحث }
$$

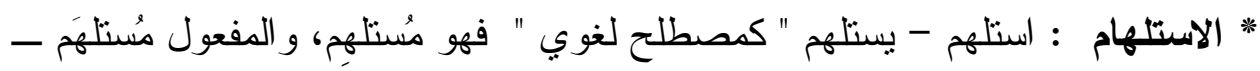

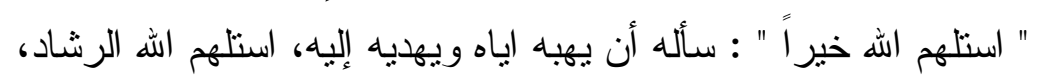

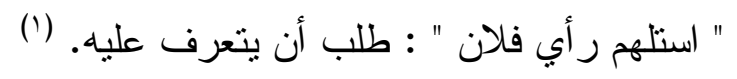

* الصولفيج : هو علم قر اءة و غناء النغمات الموسيقية.

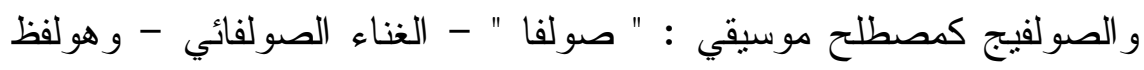

إيطالي استخدم قديماً بطريقة قر اءة النغم الموسيقي ومعناه الحرفي " نظام السلم من نغمة صول

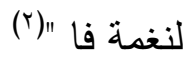

$$
\text { * الجنس : هو الهيئة اللحنية التي يعتمد عليها في تركيب المقام. }
$$

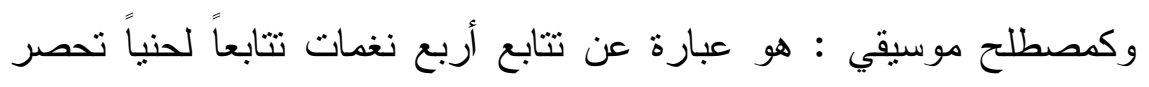

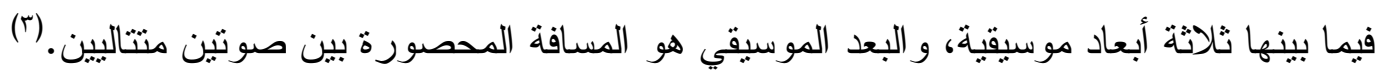

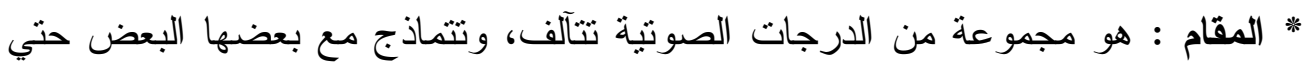

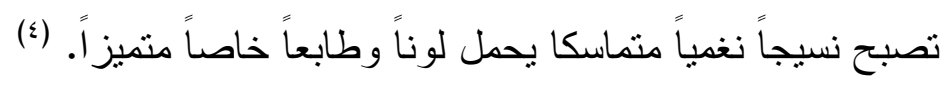

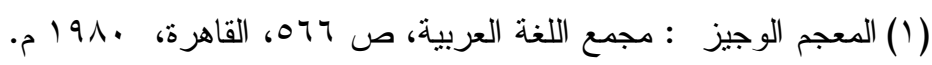

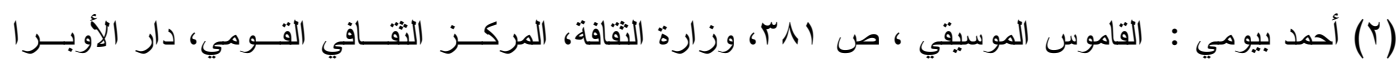

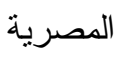

(ץ) سهير عبد العظيم محمد : أجندة الموسيقي العربية، ص ع (، دار الكثب القومية.

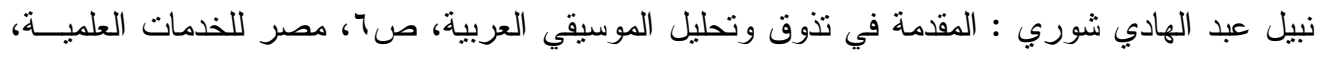

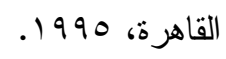

مجلة علوم وفنون الموسيقى -كلية التربية الموسيقية - المجلد الثامن والثلاثوز - يناير 1/.rم. 


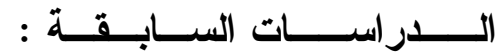

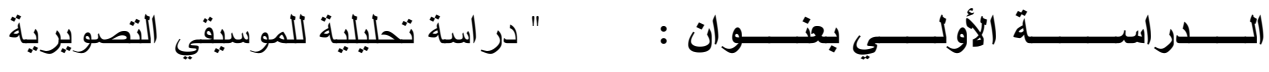

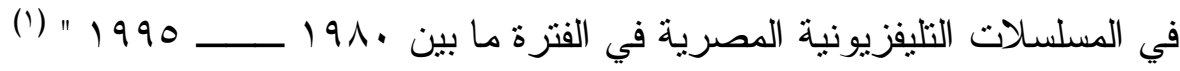

وقد هدفت هذه الدراسة إلي تحديد خصائص موسيقي المسلسل التليفزيوني المصري

وتحديد العلاقة بين دور الأغنية في المسلسل التليفزيزني والموسيقي التصويرية للمسلسلات الكانس

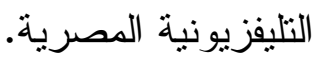

وترتبط هذه الدر اسة مع البحث الر اهن في التعرف علي اسلوب جمال سلامة في تلحين

موسيقي المسلسلات التليفزيونية.

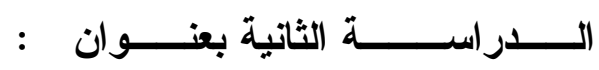

" النماذج اللحنية في الموسيقي التصويرية عند فؤاد الظاهري

و الاستفادة منها في مادة الصولفيج العربي في الكليات و المعاهد الموسيقية المتخصصة " (؟) وقد هدفت هذه الدراسة إلي التعرف علي الخصائص الفنية للموسيقي التصويرية للأفلام السينمائية عند فؤاد الظاهري، واستخدام ألحان النماذج اللحنية لأعمال فؤاد الظاهري في مجال

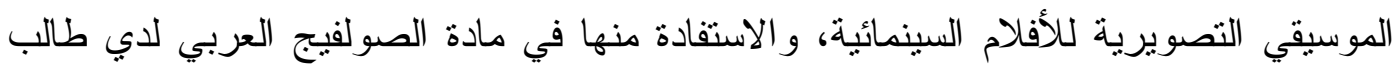

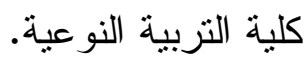

وترتبط هذه الدراسة بالبحث الر اهن في التعرف علي كيفية صياغة بعض التدريبات الصولفائية المستوحاه من النماذج اللحنية لأعمال فؤاد الظاهري في مجال الموسيقي التصويرية فئية للأفلام السينمائية، والاستفادة منها في تدريبات مادة الصولفيج العربي، كذللك يمكن الاستفادة من ذلك الاستلهام في المقدمة الموسيقية لنتر مسلسل بين القصرين لجمال سلامة في استتباط تمارين صولفائية علي نفس النمط.

( (1) هيثم سيد نظمي : " در اسة تحليلية للموسيقي التصويرية في المسلسلات التلبفزيونية المصرية في الفترة مـــا بين • 191 - 1990 " ، ، رسالة دكتور اه غير منشورة ، كلية التربية الموسيقية، جامعة حلوان، 1991 م م.

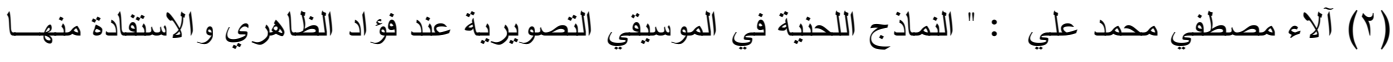
في مادة الصولفيج العربي في الكليات و المعاهد الموسيقية المتخصصة "، رسالة دكتور اه غير منشورة ،

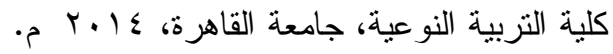

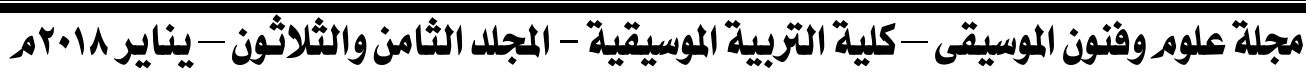


" أسلوب هاني مهني في موسيقي الفيلم والاستفادة منها في

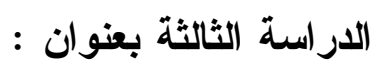
مادة الصولفيج العربي " (') وقد هدفت هذه الدراسة إلي التعرف علي الخصائص الفنية للموسيقي التصويرية للأفلام

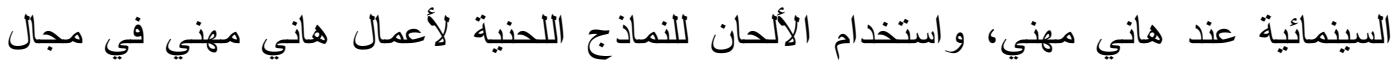

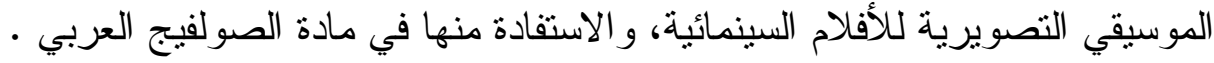

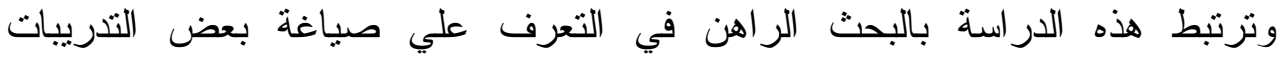

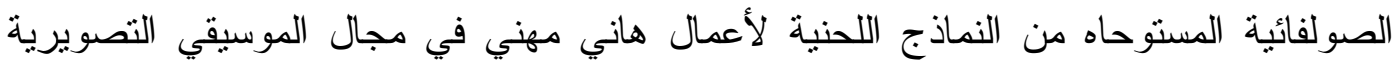

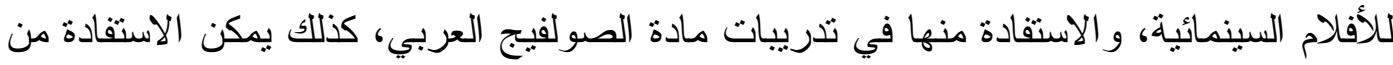
ذلك الاستلامام في المقدمة الموسيقية لتتر مسلسل بين القصرين لجمال سلامة في استتباط تمارين صولفائية علي نفس النمط.

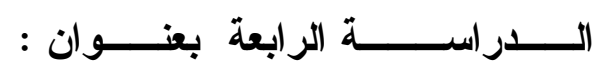

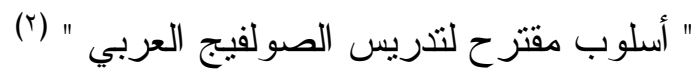
وقد هدفت هذه الدراسة إلي تطوير تدريس مادة الصولفيج العربي لرفع مستوي الأداء الفني

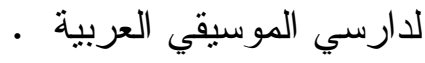
وترتبط هذه الدراسة بالبحث الر اهن في كيفية التعرف علي طرق تدريس مادة الصولفيج العبي المختلفة.

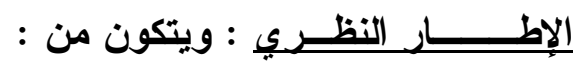
أولاً : نبذة عن حياة جمال سلامة، وجدول يوضح بعض أعماله في مجال الموسيقي التصويرية

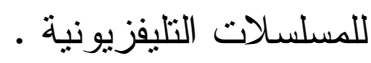
ثاتياً : نبذة عن الموسيقي التصويرية للمسلسلات التلبفزيونية في مصر.

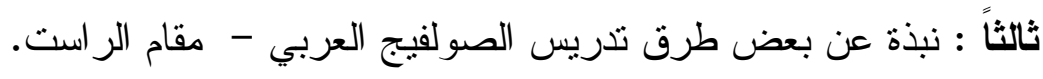

( () سيد طه مصطفي محمد : " اسلوب هاني مهني في موسيقي الفيلم والاستفادة منهـا فـي مسادة الـصولفج

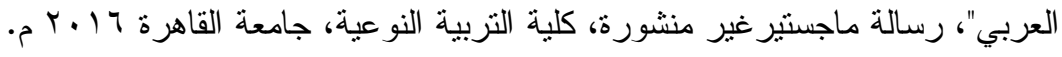

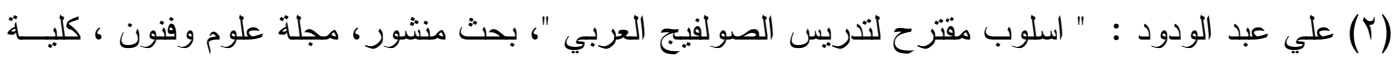

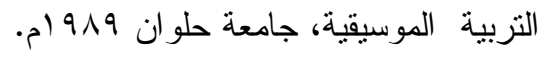

مجلة علوم وفنون الموسيقى - كلية التربية الموسيقية - المجلد الثامنوالثلاثون - يناير 1. مرم $(I T)$ 
أولاً : نبذة عن حياة جمال سلامة جدول يوضح بعض أعماله في مجال الموسيقي التصويرية لالمسلسلات التليفزيونية .

\section{نبذة عن حياة جمال سلامة:}

- - ولد جمال سلامة بالقاهرة في الخامس من أكتوبر 0 ــ 19 م.

- ينتمي إلي عائلة موسيقية، فو الده حافظ سلامة كان عازف بارع علي علي آلة التزومبيت

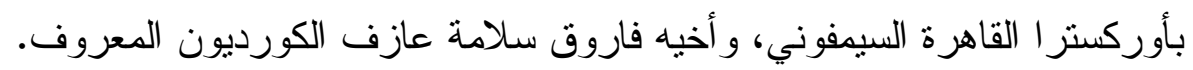

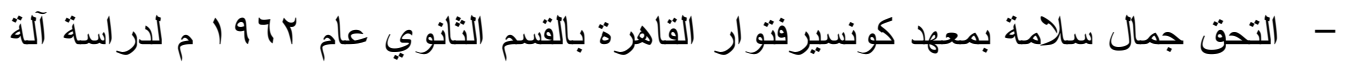

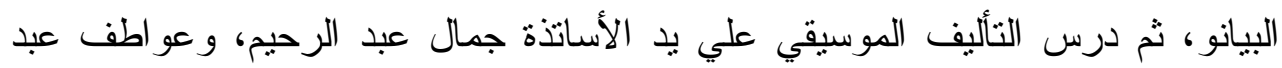

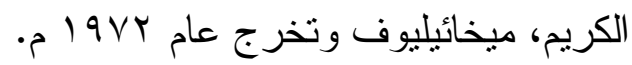
- - رشح لبعثة للإتحاد السوفيتي بعد تخرجها، وهناك درس علئ علي يد المؤلف الروسي أرام خاتثاتوريان بكونسيرفتو ار روسيا. - حل علي أعلي شهادة في التأليف الموسيقي عام

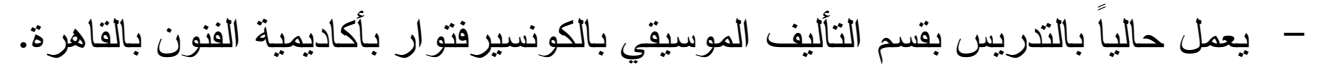

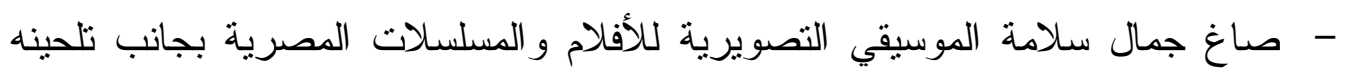
للقوالب الغنائية المختلفة لأهم المطربين المصريين منل هاني شاكر، محمد ثروت، عفاف راضي، فايزة أحدد، وردة، علي الحجار، زينب يونس، صباح، وشادية... و غير هم من المطربين و المطربات. - من اهم الموسيقات التصويرية التي صاغها جمال سلامة للأفلام المصرية نذكر منها

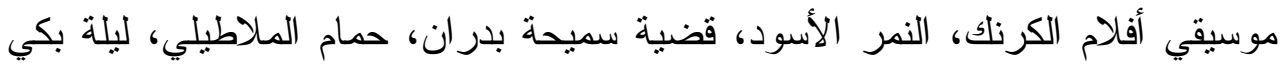

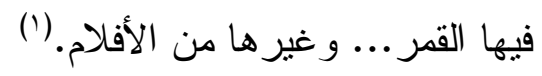

ص

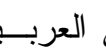

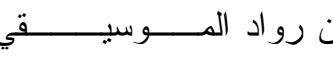

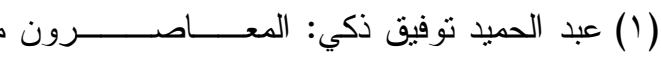

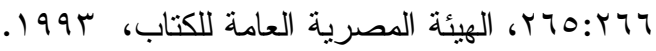


جدول يوضح بعض أعماله في مجال الموسيقي التصويرية للمسلسلات التليفزيونية (1)(')

\begin{tabular}{|c|c|c|c|}
\hline المخرج & المؤلف & اسم المسلسل & b a n a n \\
\hline محمد فاضل & وحيد حامد & أحلام الفتي الطائر & 1 \\
\hline ابر اهيم الثقنقير ي & بهجت قر & أرض النفاق & r \\
\hline انعام محمد علي & فتحية العسال & 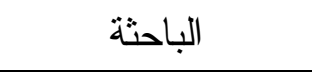 & r \\
\hline انعام محمد علي & عبد الرحمن فهمي & الحب و أثنياء أخري & $\varepsilon$ \\
\hline ابر اهيم الثقنقيري & أحمد رجب & الحب وسنينه & 0 \\
\hline عبد العزيز السكري & سمير عبد العظيم & الصبر في الملاحات & 7 \\
\hline حسام الدين مصطفي & فتحي غانم & الفرسان & v \\
\hline ابر اهيم الثقنقيري & بهاء الدين محمد & أو لاد الأصول & $\wedge$ \\
\hline يوسف مرزوق & نجيب محفوظ & بين القصرين & 9 \\
\hline ابر اهيم الثنقنقيري & احسان عبد القدوس & أين عمري & 1. \\
\hline مجدي أبو عميرة & محمد صفاء عامر & ذئاب الجبل & 11 \\
\hline أحمد طنطاوي & عبد الحميد جودة السحار & محمد يا رسول الله & IT \\
\hline يوسف مرزوق & نجيب محفزظ & قصر الثوق & $1 \pi$ \\
\hline حمدي الإبر انشي & يسري الجندي & حصاد الثر & $1 \varepsilon$ \\
\hline أنعام محمد علي & نادية رشـاد & دعوة للحب & 10 \\
\hline محمد السيد عيسي & علي عبد القوي & أو لاد حضرة الناظر & 17 \\
\hline حسين كمال & توفيق الحكيم & عودة الروح & iv \\
\hline ابر اهيم الثقتقيري & بهاء الدين ابر اهيم & دعاء النهار & 11 \\
\hline يوسف مرزوق & نجيب محفوظ & قشتمر & 19 \\
\hline ابر اهيم الثقنقيري & بهجت قمر & عيون & $r$. \\
\hline
\end{tabular}

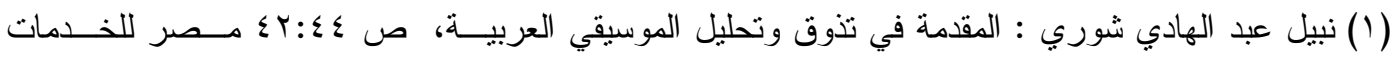

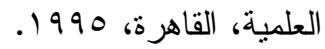

مجلة علومروفنون الموسيقى -كلية التربية الموسيقية - المجلد الثامن والثلاثوذ - يناير 1 ا+rمر 
ثاتياً : نبذة عن الموسيقي التصويرية للمسلسلات التليفزيونية في مصر : - ظهرت الأعمال الدرامية في مصر بعد بدء بث الإرسال التلفزيوني في اب يوليو .197.

- كان الاهتمام الموسيقي المستخدم في هذه الأعمال الدر امية التلفيزيونية موجه للمقدمة

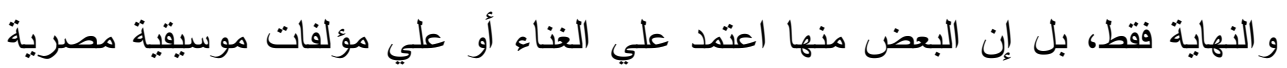
لبست مؤلفة او معدة سخصيصاً لهذا العمل. - يوجد أعمال درامية أخري تعتمد علي مقاطع من الموسيقي العالمية، وذلك ما يسمي بالإعداد الموسيقي، ونوضع هذه المقاطع الموسيقي كخلفية للمشاهد الدر امية.

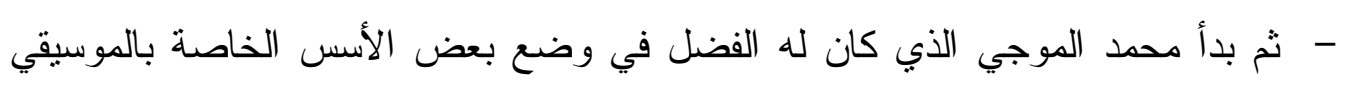

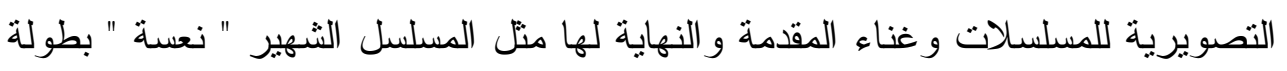
و غناء مها صبري. - ثم ظهر جيل من العازفين علي بعض الآلات الغربية مثل عمر خورشيد علي آلة

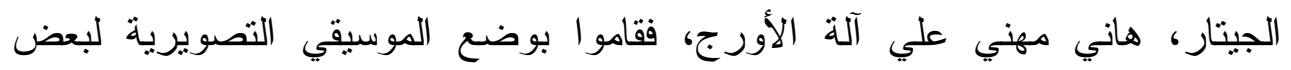

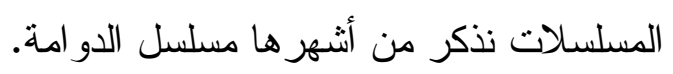

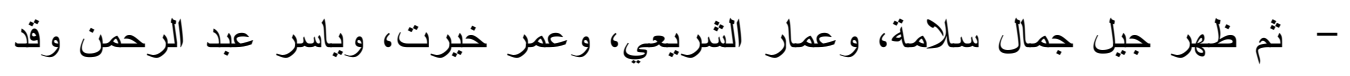

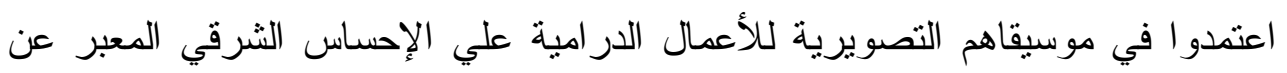

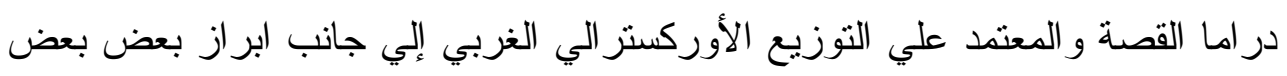

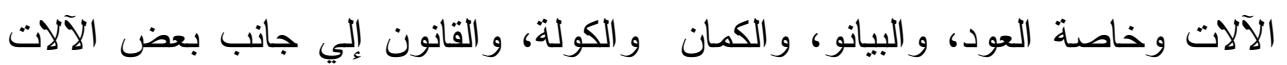

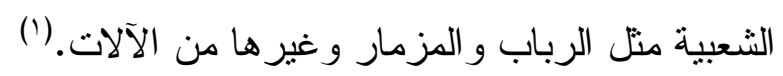

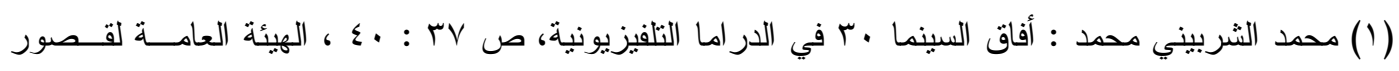

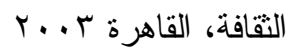

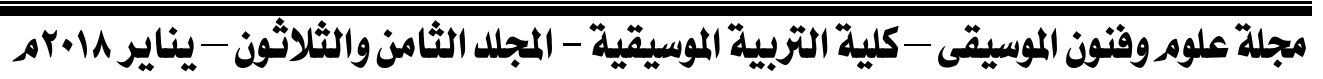
$(I M r \cdot)$ 
ثنالثاً : نبذة عن بعض طرق تدريس الصولفيج العربي - مقام الراست.

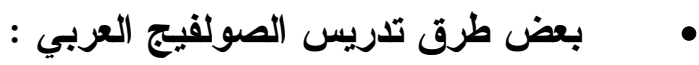

\section{•}

وهي من أهم الطرق انتشاراً، وهي تقوم علي قر اءة وغناء التمارين صولفائياً من خلال

المقامات العربية المختلفة.

طريقة لتدريس الصولفيج : لمغنه

وهي تعتمد علي أسس الدمج بين تدريس المقامات و الأجناس العربية المختلفة من خلال قالب الموشحات و التذوق وتقوم علي استتناج درجات الدقام أو الجنس من خلال ألحان الدان شعبية في الدفام المر اد تدريسه.

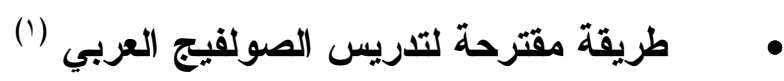

تعتدد هذه الطريقة علي ربط ودمج المقام الأساسي وجنسيه الأصل و الفرع و الربط بين مختلف

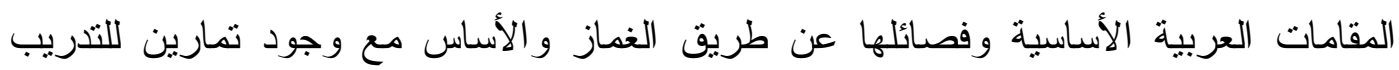
عليها، كما اهتمت أيضاً بالمسافات التي توجد بالأجناس.

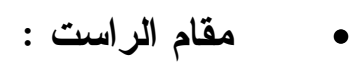

معناه المستقيم، و هو من أبرز المقامات العربية، ويعتبره البعض أنه المقام الأساسي لها وأكثرها

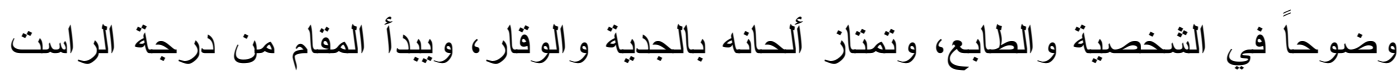
حتي درجة الكردان. (r) الأن

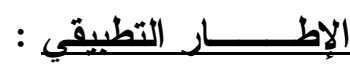
عينة البحث : المقدمة الموسيقية لتتر مسلسل بين القصرين للملدن جمال سلامة.

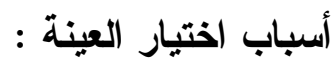
اختار الباحث هذا التتر لمقدمة مسلسل بين القصرين للملدن جمال سلامة للأسسباب

( (1) سهير المصري :" طريقة مقترحة لندريس الصولفيج العربي "،رسالة ماجستير غير منثورة، كلية الثربيــة الموسيقية، جامعة حلو ان، 1991 1 (r) سهير عبد العظيم محمد : أجندة الموسيقي العربية، ص ع عا، دار الكتب القومية.

مجلة علوم وفنون الموسيقى -كلية التربية الموسيقية - المجلل الثامن والثلاثون -يناير 11.ام. 
1-مقام الراست وهو من المقامات الأساسية الني تدخل في منهج الفرقة الأولي لمادة الصولفيج العربي لقسم التربية الموسيقية لكليات التربية النوعية.

r- ب الاتقالات اللحنية البسيطة.

ץ- بساطة اللحن في جمل سلمية صاعدة وهابطة، و التتابع اللحني الهابط و النوت الطويلة.

$$
\text { ع- تعدد الموازين }
$$

ه- استخدم الملحن في هذا العمل آلات التخت الثرقي وكل آلة لها صولو خاص مثل القانون و العود و الناي بجاتب مجموعة آلات الوتريات و الإيقاع.

1-صياغة هذه المقدمة قريبة البناء من قالب التحميلة في استخدام آلات التخت الثرقي.

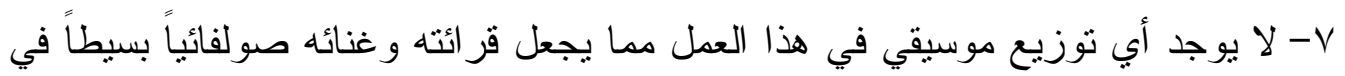

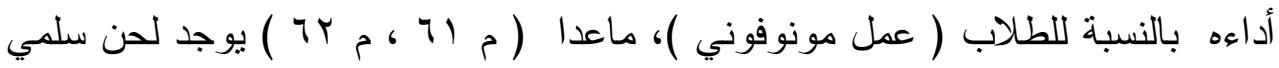
من آلة الناي في نوتة علي الزمن نوار مصاحب للحن الأساسي بمكن حذفه أثناء غناء هذا الجزء و لا يؤثر علي العمل.

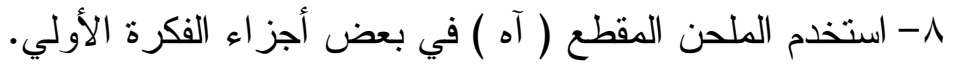

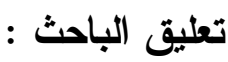
احتوي هذا التتر علي المقامات والأجناس الآتية : • (مقام راست علس درجة الر است.

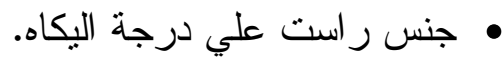
• جنس راست علي درجة النوي. • جنس راست علي درجة الكردان.

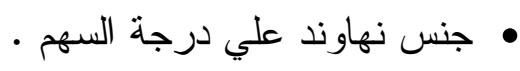
• جنس نهاوند علي درجة النوي. • جنس جهاركاه علي درجة الماهور .

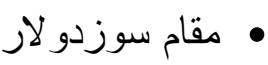




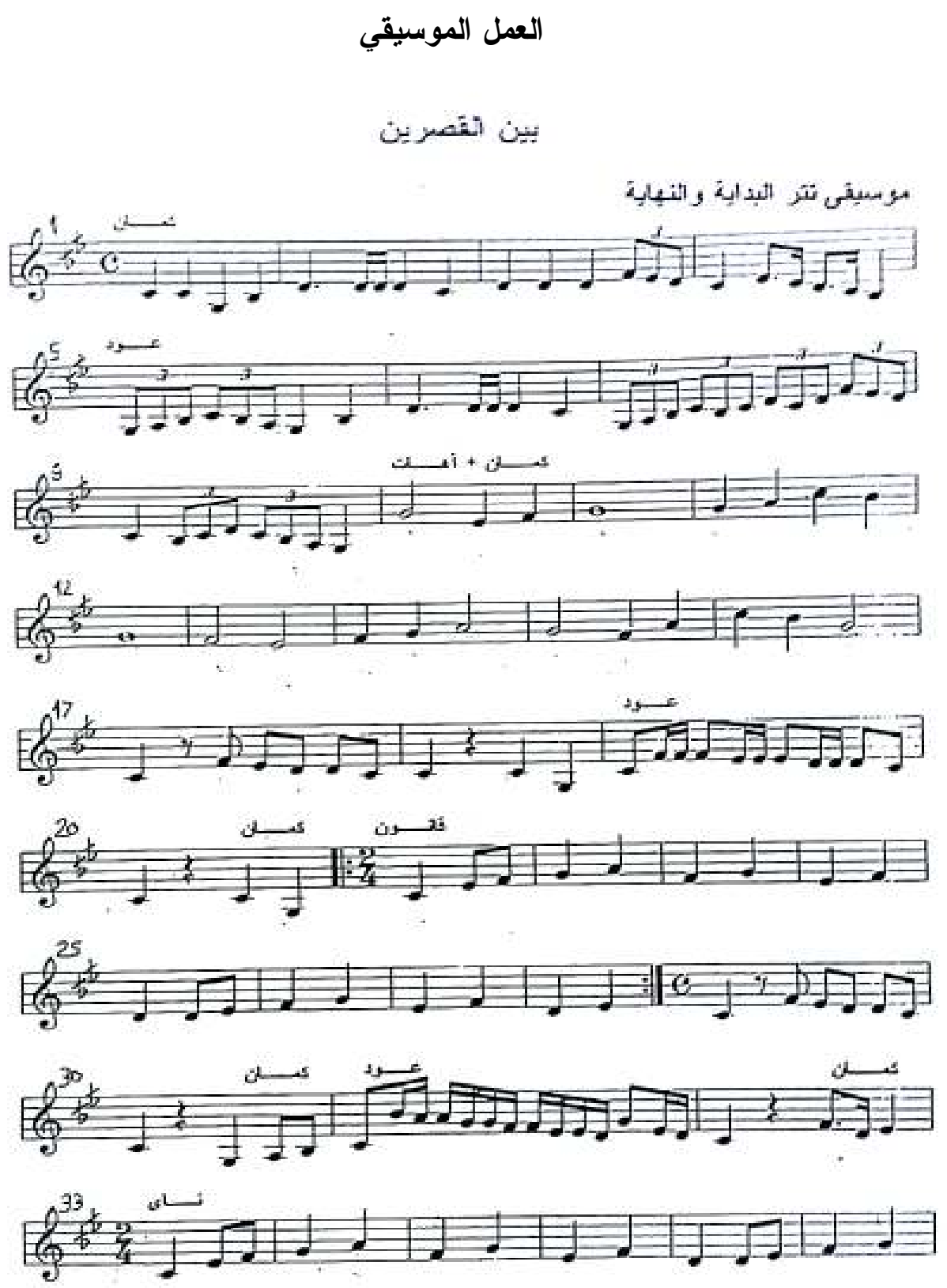

مجلة علوم وفنون الموسيقى - كلية التربية الموسيقية - المجلد الثامنوالثلاثون - يناير 11. مـ

(ITHT) 

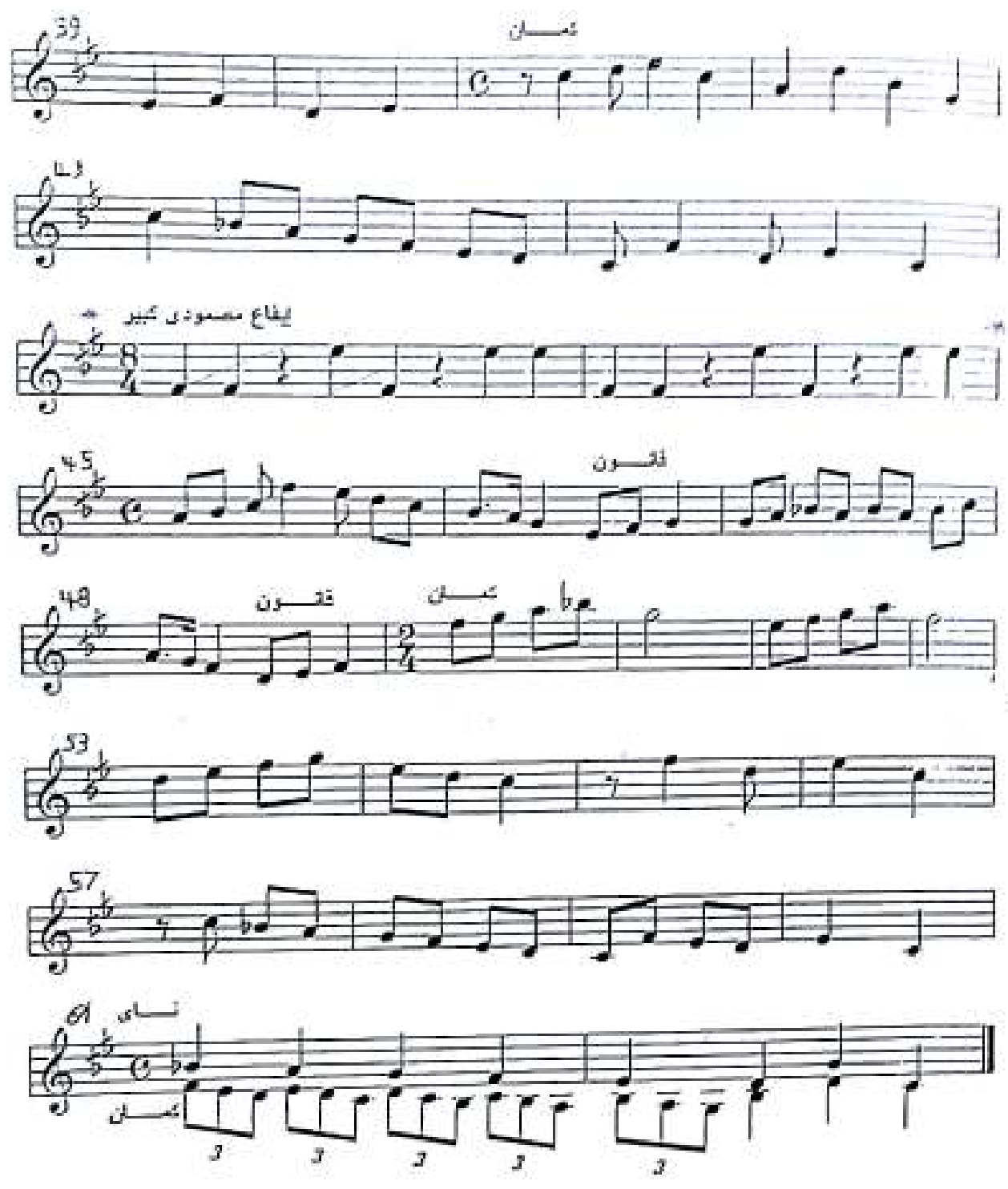

التتر الموسيقي لمقدمة مسلسل بين القصرين

البطاقة التعريفية : • • اسم العمل : مقدمة مسلسل بين القصرين

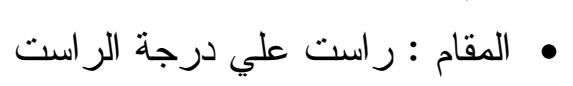

مجلة علوه وفنون الموسيقى -كلية التربية الموسيقية - المجلد الثامنوالثلاثون - يناير 1 ا.rم

(ITY ) 


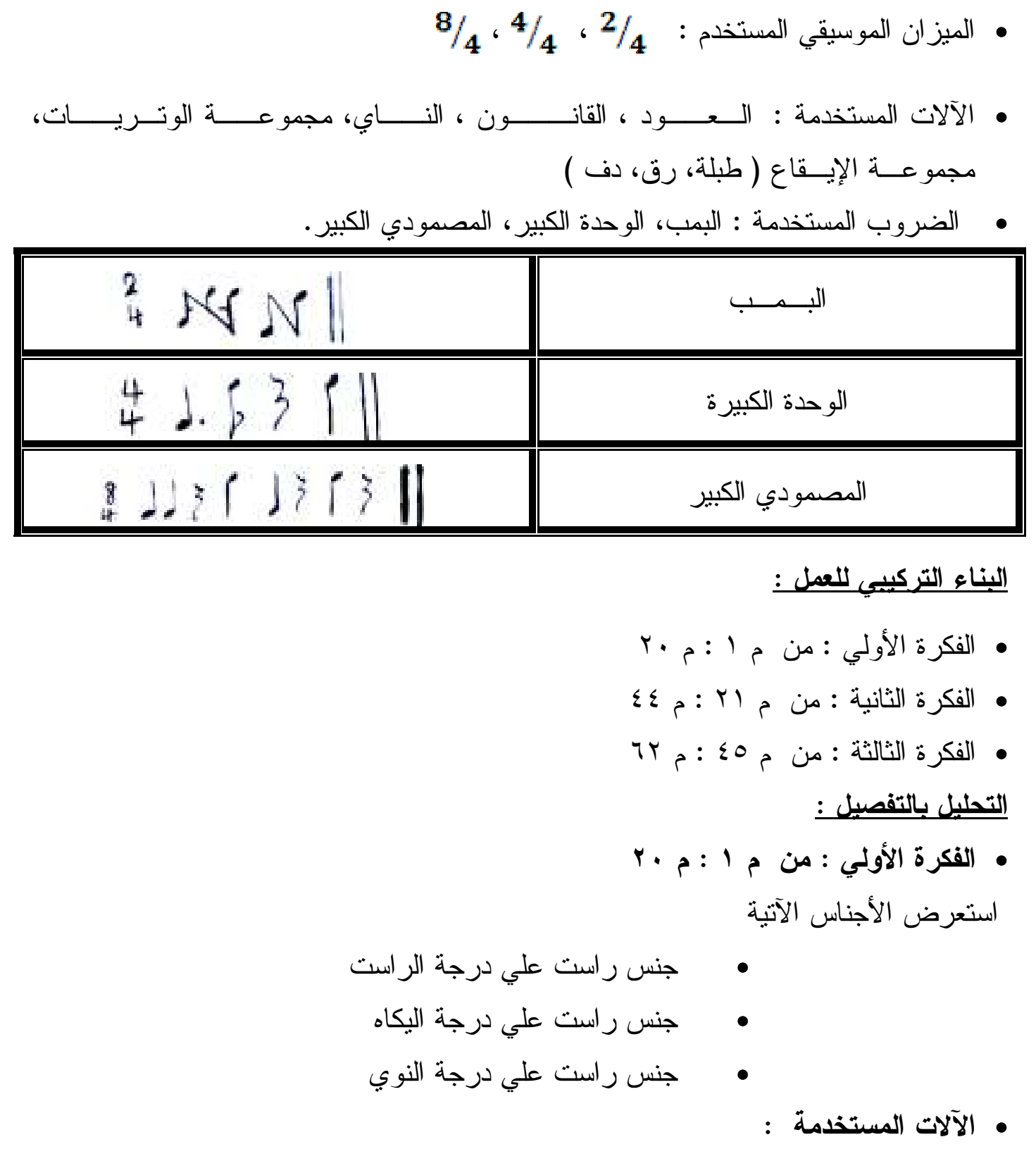

مجموعة آلات الونريات - آلة العود - غناء بعض الجمل بالمقطع الغنائي (آه) 


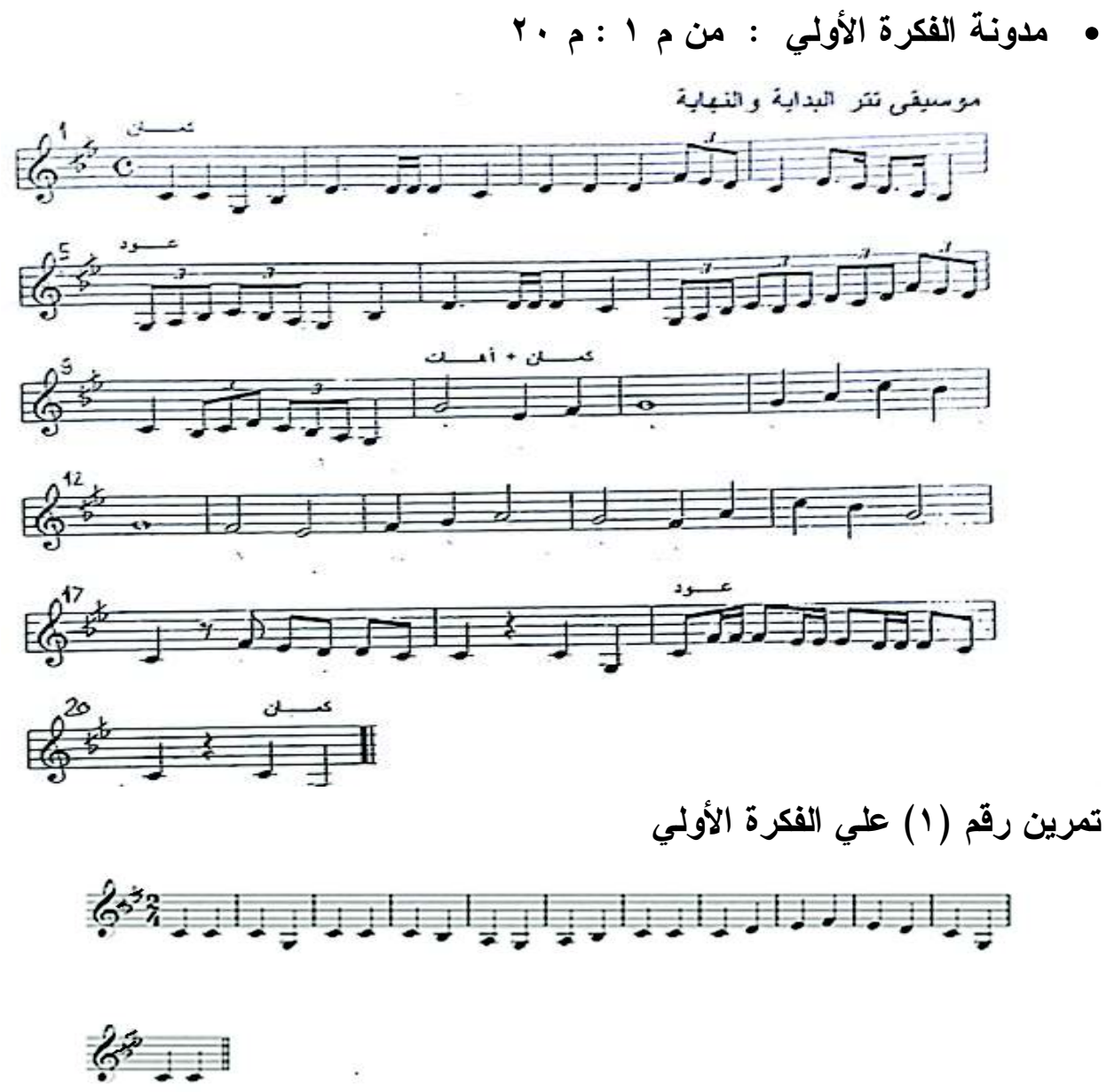

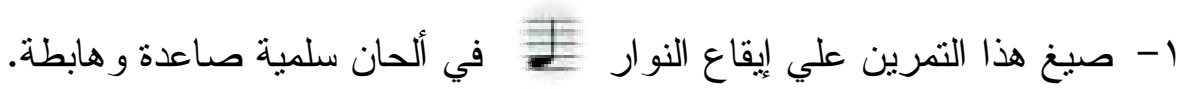
ץ- هدفت صياغة هذا التمرين للتأكيد علي جنس راست علي درجة اليكاه، وجنس راست

$$
\text { تمرين رقم (r) علي داجة النوي. }
$$

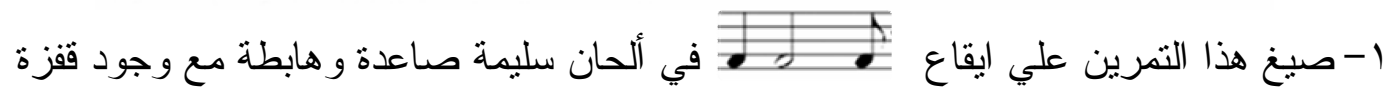
من درجة الكردان إلي درجة النوي بمسافة رابعة تامة هابطة.

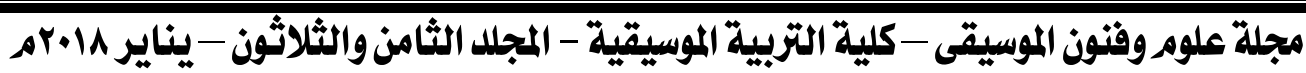


ץ- هدفت صياغة هذا التمرين التأكيد علي جنس راست علي درجة الراست، وجنس

$$
\text { تمرين رقم (ץ) علي الفكرة الأولي درة النوي. }
$$

( يعتمد هذا التمرين علي ألحان الفكرة الأولي كلها )
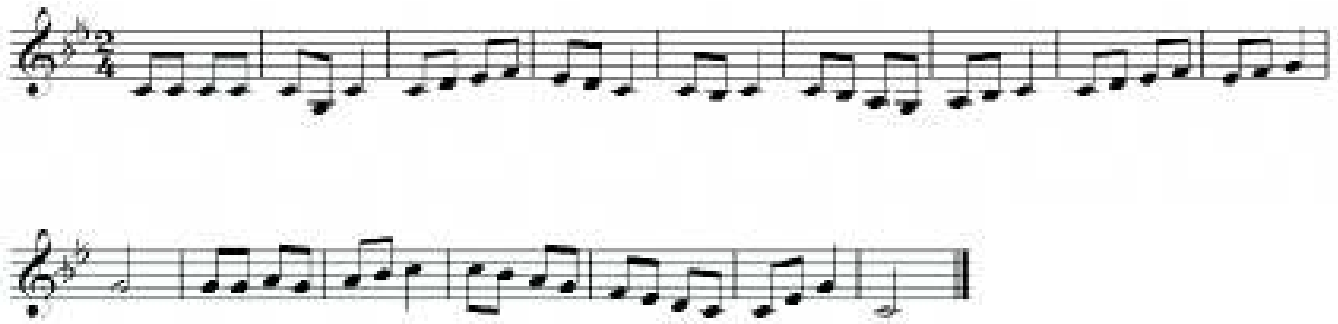

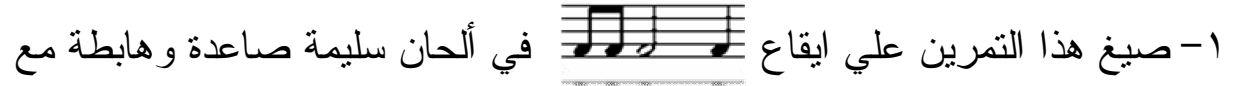

وجود ققزة من درجة الكردان إلي درجة النوي بمسافة رابعة تامة هابطة.

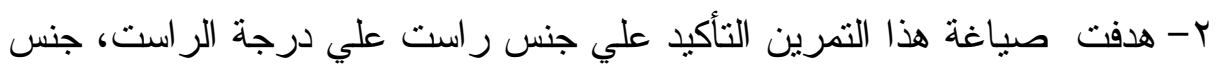

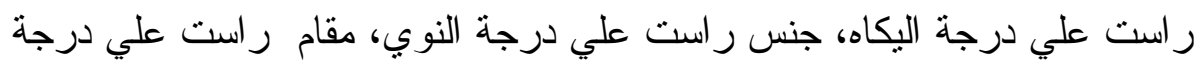

$$
\text { الر است. }
$$

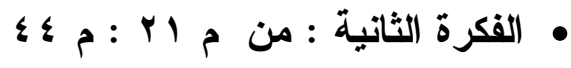
استعرض الأجناس الآتية

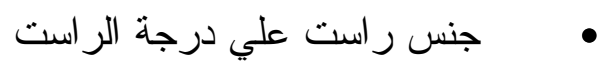

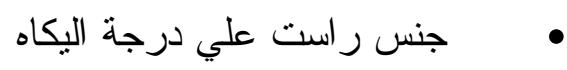

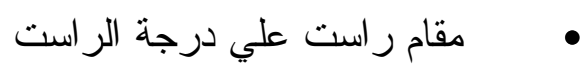

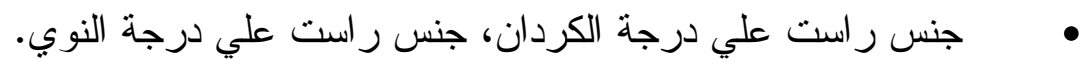

• الستعر اض لمقام السوزدو لار.

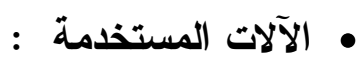

آلة القانون، مجموعة آلات الإيقاع، مجموعة آلات الوتريات، آلة الناب

، غناء بعض الجمل بالمقطع الغنائي ( آه )

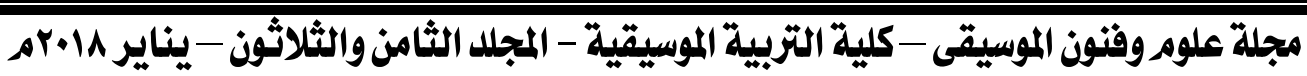


• مدونة الفكرة الثانية : من م اب : م ع ؛
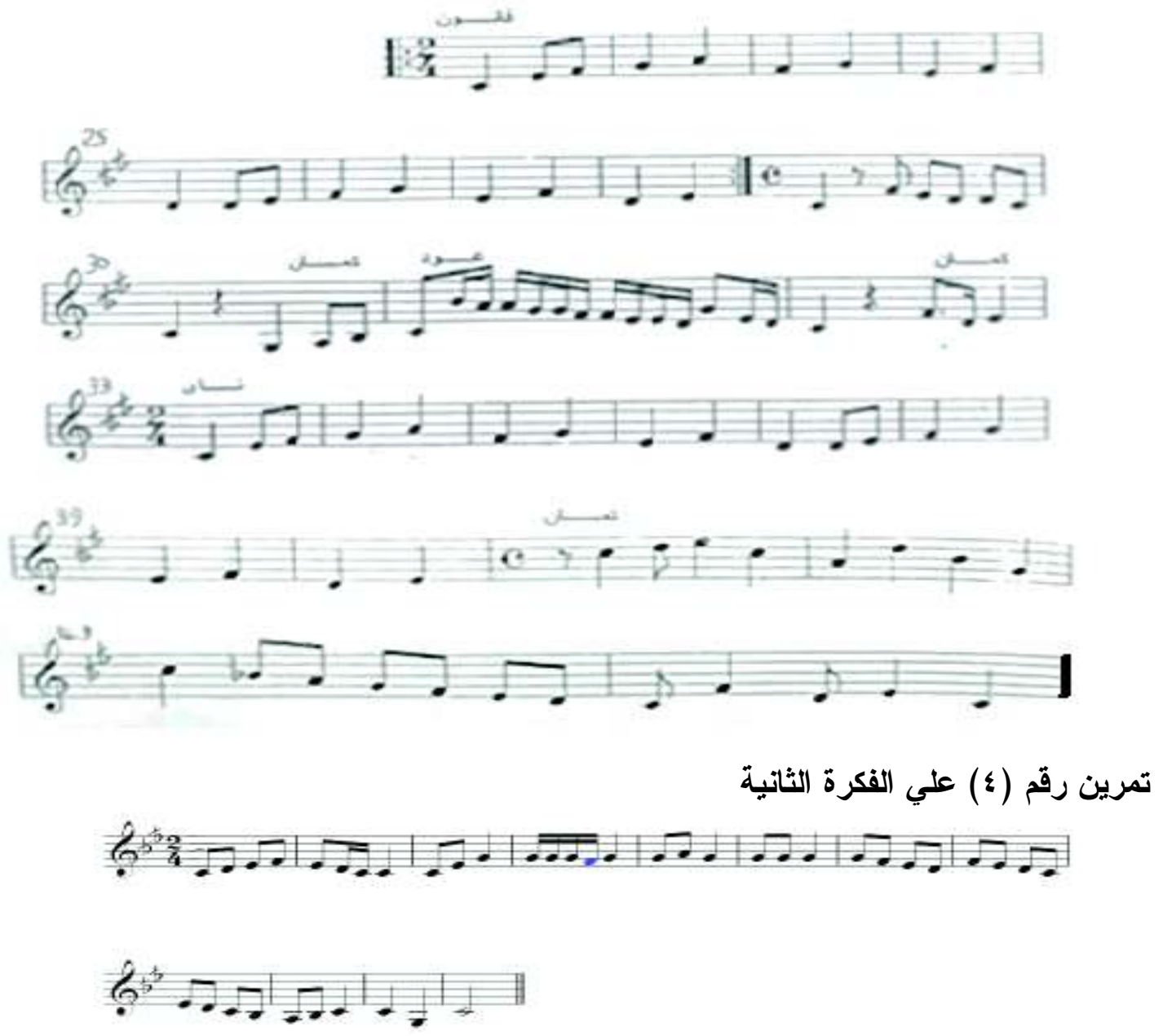

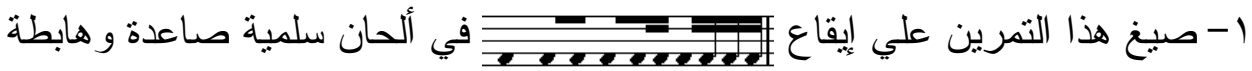

$$
\text { ومنكررة. }
$$

ץ- هدفت صياغة هذا التمرين التأكيد علي جنس راست علي درجة الر است، جنس راست علي درجة اليكاه

مجلة علوم وفنون الموسيقى - كلية التربية الموسيقية - المجلل الثامنوالثلاثوذ - يناير 11. مر 


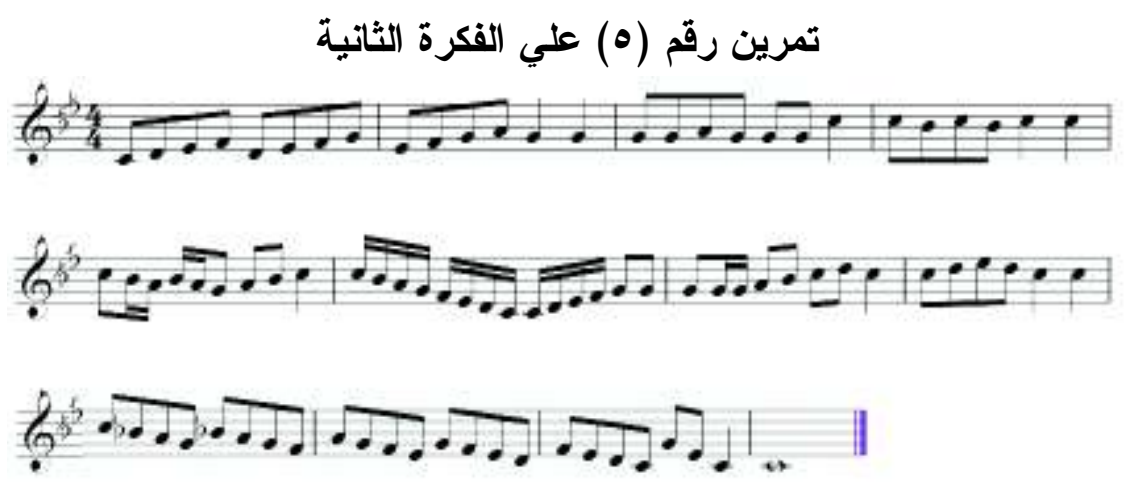

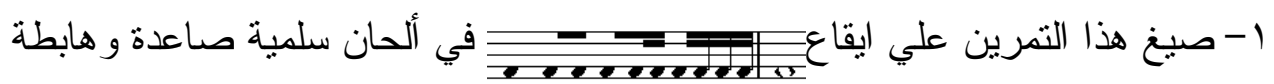

$$
\text { ومتكررة و أربيج هابط. }
$$

r- هدفت صياغة هذا التمرين التأكيد علي جنس راست علي درجة الر است، جنس

راست علي درجة النوي، جنس راست علي درجة الكردان، مقام سوزدولار علي

$$
\text { درجة الر است. }
$$

\section{تمرين رقم (؟) علي الفكرة الثانية}

( يعتمد هذا التمرين علي ألحان الفكرة الثانية كلها )

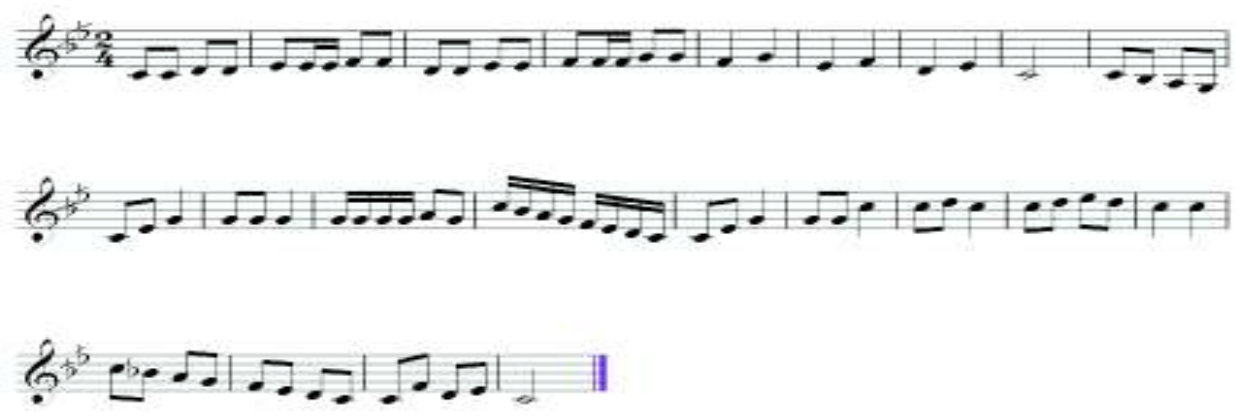

ا - صيغ هذا التمرين علي ايقاع

الثانية كلها و علي التتابع اللحني الصاعد و الهابط، و الأربيجات الصاعدة، و الألحان السلمبة الهابطة، و الققز ات الر ابعة التامة الصاعدة.

ץ- هدفت صباغة هذا التمرين التأكيد علي جنس راست علي درجة الر است، جنس راست است

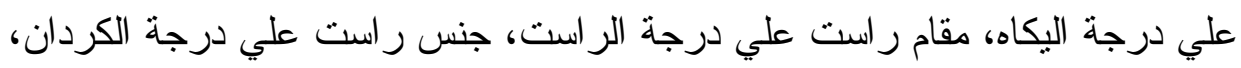

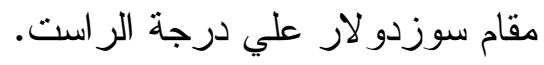

مجلة علوه وفنون الموسيقى -كلية التربية الموسيقية - المجلد الثامنوالثلاثون - يناير 11. مر 


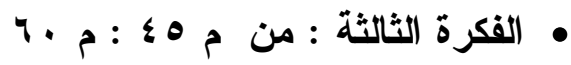

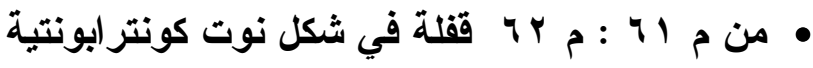
استعرض الأجناس الآتية

• جنس راست علي درجة الأثة الكردان.

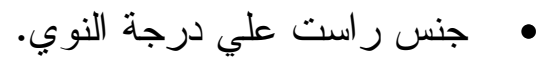

• جنس نهاوند علي درجة النوي.

• جنس نهاوند علي درجة السهم، جنس عجم علي درجة الماهور .

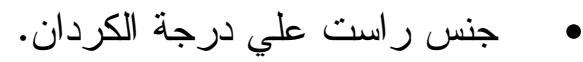

• • مقام السوزدو لار علي درجة الراست.

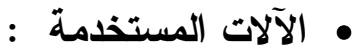

مجموعة آلات الإيقاع، مجموعة آلات الوتريات، آلة القانون مع آلة الناي، آلة العود

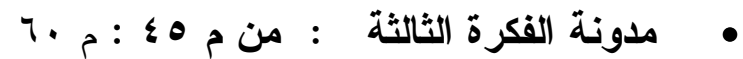

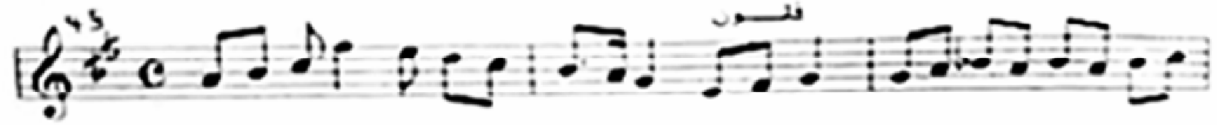

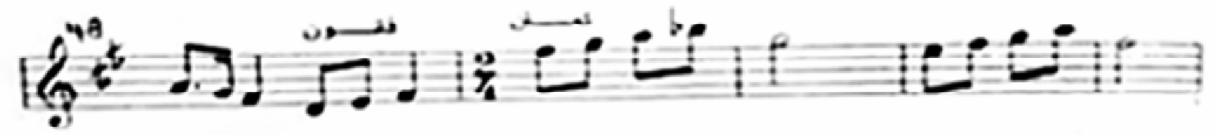
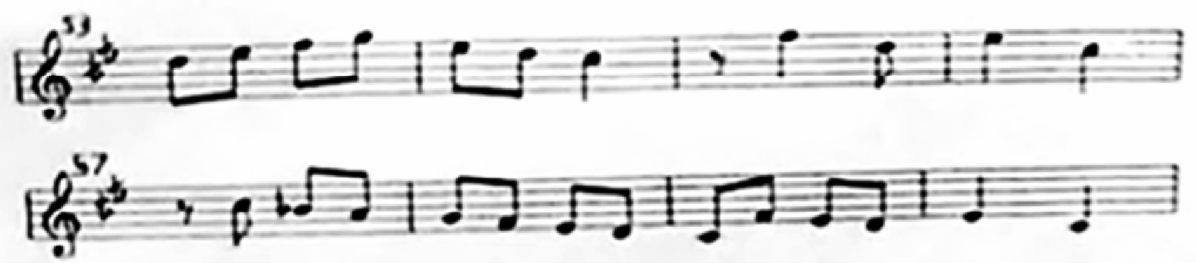

تمرين رقم (V) علي الفكرة الثالثة

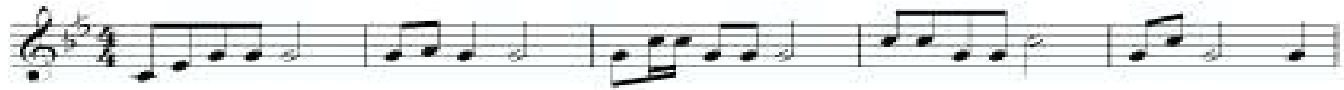

$6^{+} \ldots \ldots \ldots \ldots+\ldots$

$65^{5} \cdots+1$

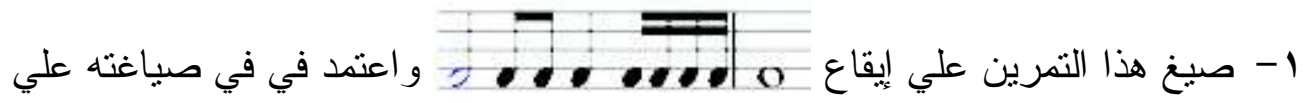

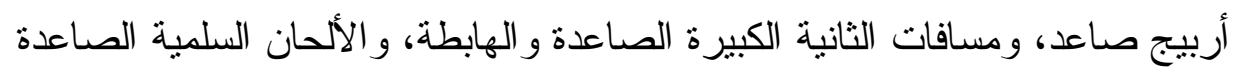

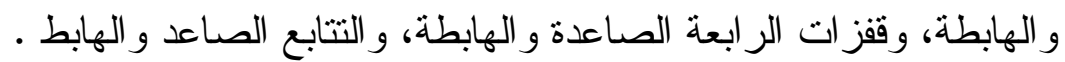

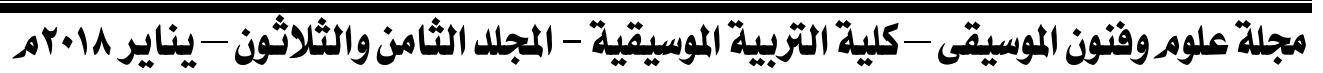


ץ- هدفت صياغة هذا التمرين التأكيد علي جنس راست علي درجة النوي، جنس راست علي درجة الكردان، جنس نهاوند علي درجة النوي. تمرين رقم (^) علي الفكرة الثالثة

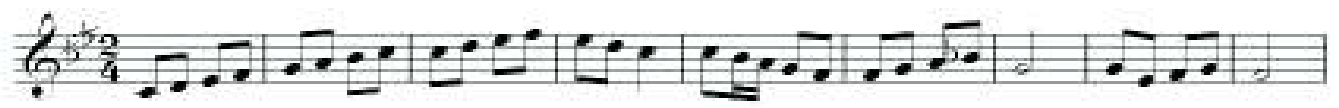

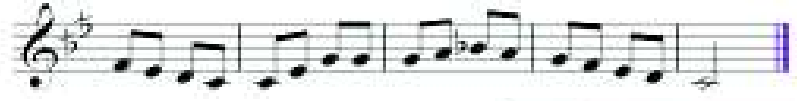

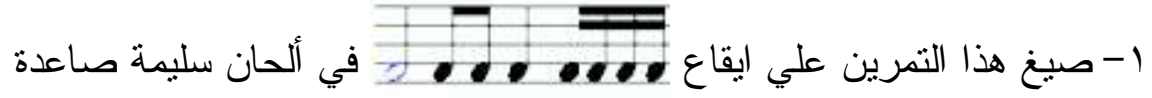

و هابطة مع وجود مسافة قفـزة الثالثة الصغيرة الهابطة.

r- هدفت صياغة هذا التمرين التأكيد علي مقام راست علي درجة الر است، جنس راست علي درجة الكردان، جنس عجم علي الجهاركاه.

تمرين رقم (9) علي الفكرة الثالثة ( يعتمد هذا التمرين علي ألحان الفكرة الثالثة كلها )

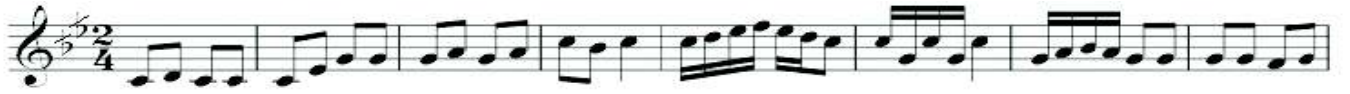
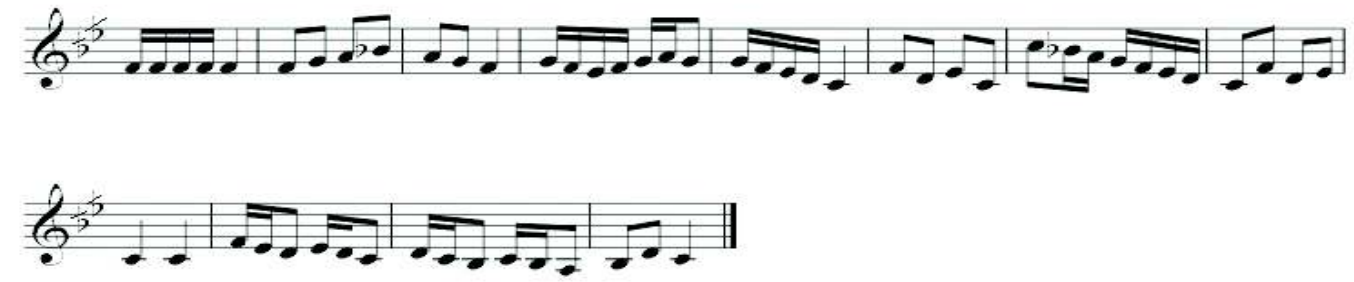

ا- صيغ هذا التمرين علي ايقاع

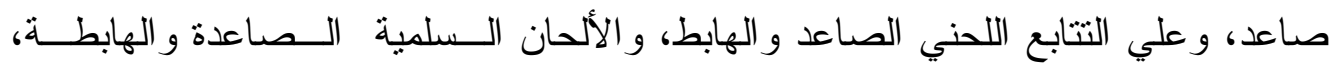
و القفز ات الر ابعة التامة الهابطة و الصاعدة، و الثالثة الكبيرة و الصغيرة الهابطة و الــصاعدة، و الثالثة المتوسطة الصاعدة. ז- هدفت صياغة هذا التمرين التأكيد علي جنس راست علي درجة الكردان، جنس راست علي درجة النوي، جنس نهاوند علي درجة النوي، جنس عجم علي درجــة الجهاركــاه، مقــام سوزدو لار علي درجة الر است. 
• خطوات سير الجلسة الأولي " للفكرة الأولي " من التـــر الموســيقي لمقدمـة بـين القصرين لجمال سلامة

تحتوي هذه الفكرة علي ثلاث تمارين مستلهمة منها :

1-يتم سماع التتر الموسيقي للمقدمة الموسيقية لمسلسل بين القصرين من خلال السي دي

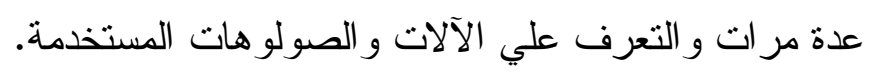

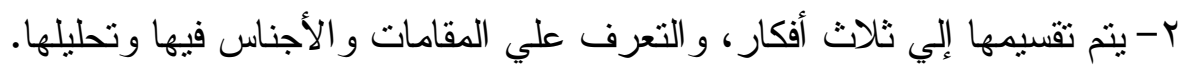

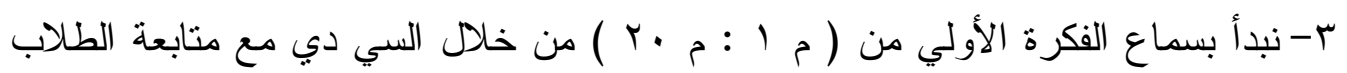

للمدونة الموسيقية الخاصة بهذا الجز ء والتعرف علي الآلات المستخدمة.

$$
\text { ع - قر اعة صولفائية للفكرة الأولي من قبل الطلاب. }
$$

ه- يقوم كل طالب بغناء هذه الفكرة بمصاحبة آلة العود من قبل الأستاذ.

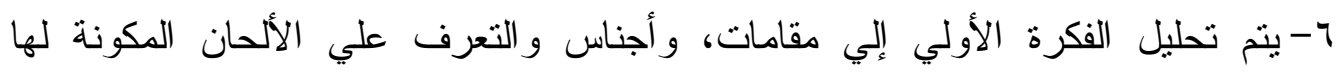

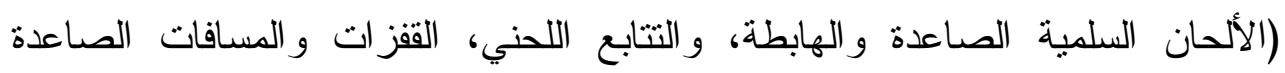

$$
\begin{aligned}
& \text { و الهابطة، و الإيقاعات ). } \\
& \text { - - يقوم الطلاب بغناء هذه الفكرة صولفائياً. }
\end{aligned}
$$

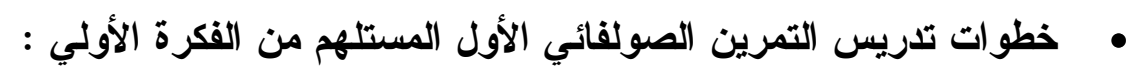

1- ينم عرض التمرين الأول الصولفائي المستلهم من لحن الفكرة الأولي.

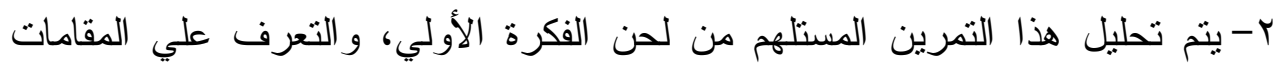

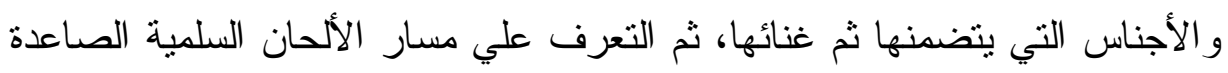

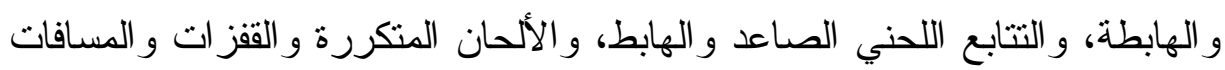

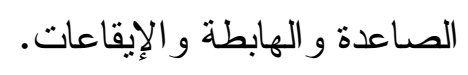

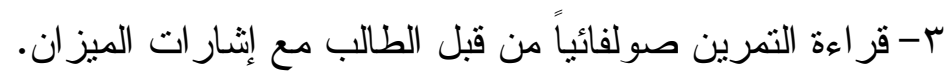

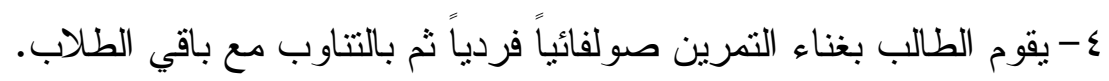

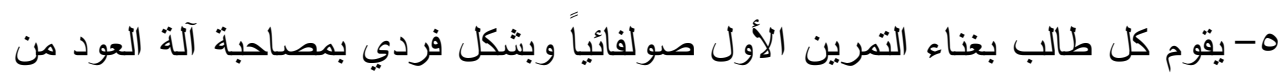
قبل الأستاذ.

צ-وفي النهاية يتم غناء التمرين صولفائياً بشكل جماعي من قبل الطلاب مرة بدون مصاحبة آلة العود ومرة أخري بمصاحبة آلة العودئ 
خطوات سير الجلسة الثانية لتدريس التمرين الثاني المستلهم من

التتر الموسيقي لمقدمة بين القصرين لجمال سلامة

1- يتم عرض التمرين الثاني الصولفائي المستلهم من لحن الفكرة الأولي.

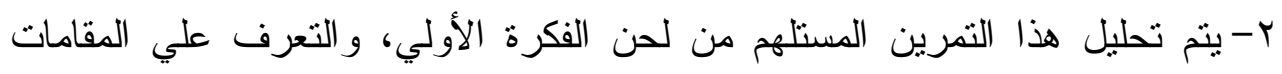

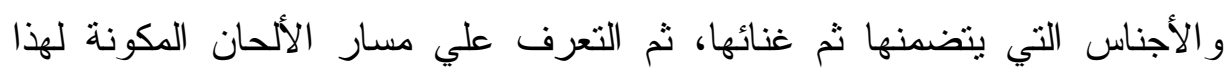

$$
\text { التمرين و الإيقاعات المستخدمة. }
$$

ب- قر اءة التمرين صولفائياً من قبل الطالب مع إنثار ات المباعة المبزان.

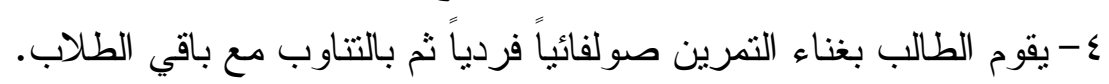

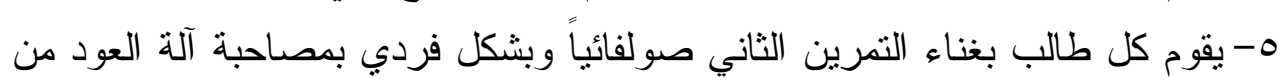
قبل الأستاذ.

צ-وفي النهاية يتم غناء التمرين صولفائياً وجماعياً من قبل الطلاب مرة بدون مصاحبة آلة العود ومرة أخري بمصاحبة آلة العود النداه

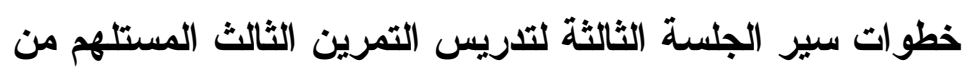

التتر الموسيقي لمقدمة بين القصرين لجمال سلامة الجئة

1- ينم عرض التمرين الثالث الصولفائي المستلهم من لحن الفكرة الأولي.

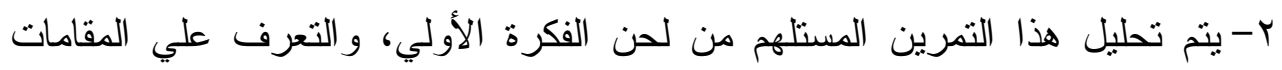

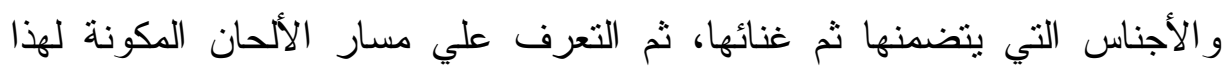

$$
\text { التمرين و الإيقاعات المستخدمة. }
$$

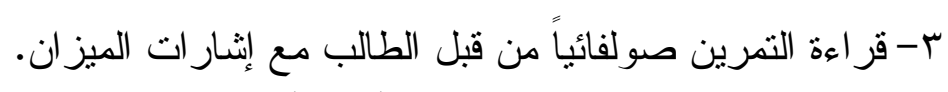

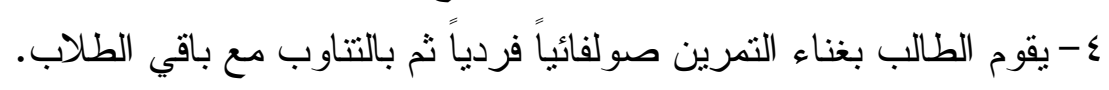

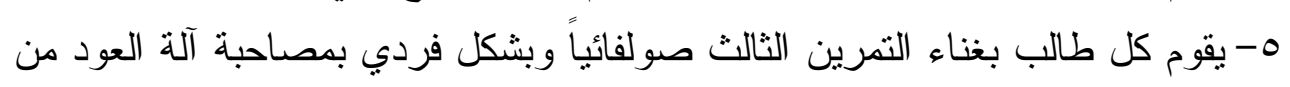

$$
\text { قبل الأستاذ. }
$$

ج-وفي النهاية يتم غناء التمرين صولفائياً بشكل جماعي من قبل الطلاب مرة بدون

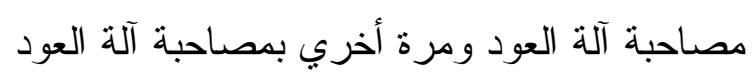

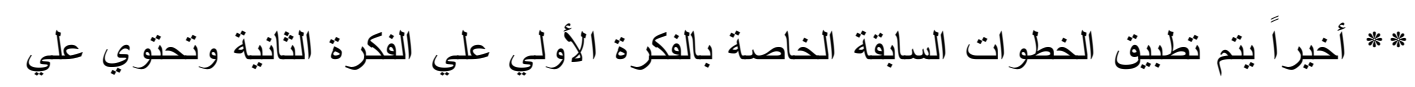

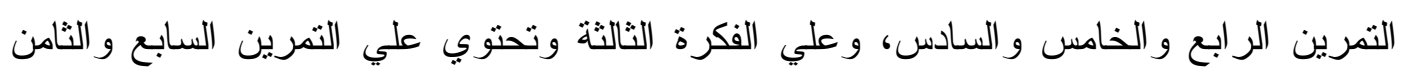
و التاسع من خلال الجلسات من الجلسة الر ابعة حتي الجلسة التاسعة.

مجلة علومروفنون الموسيقى -كلية التربية الموسيقية - المجلد الثامنوالثلاثوذ - يناير 1/.rمر 


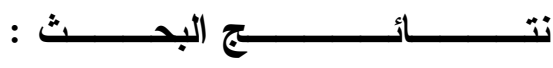

من خلا الارسة التحليلية التي قام بها الباحث لاحظ الآتي :

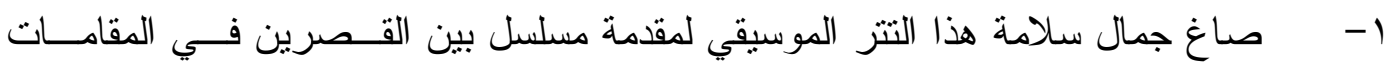

$$
\text { و الأجناس الآتية }
$$

• مقام راست علي درجة الر است.

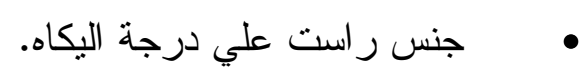

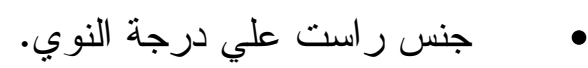

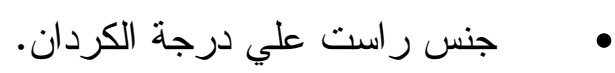

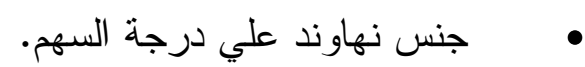

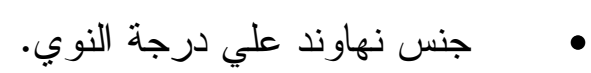

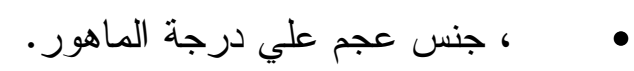

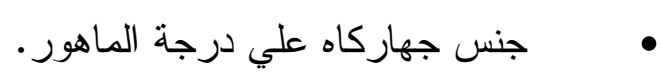

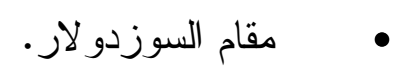

r- الانتقال بين المقامات ومختلف الأجناس المكونة للعمل كانت بكل سهولة وحرفية، ودون

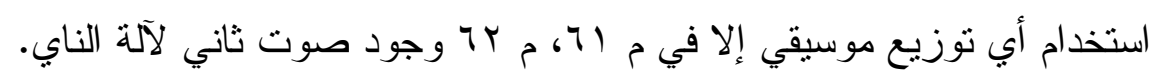

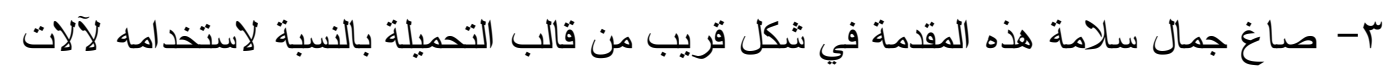

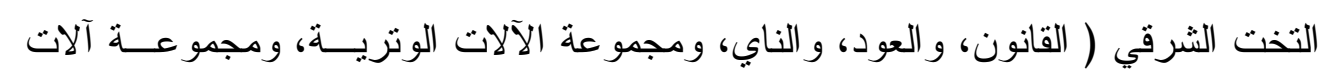

$$
\text { الإيقاع ). }
$$

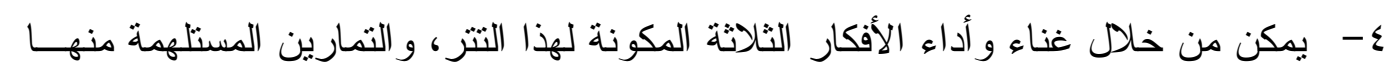

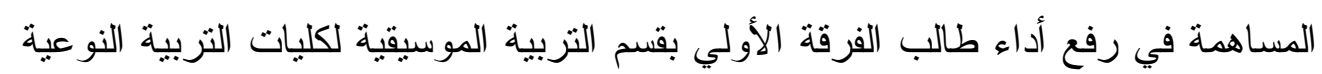

$$
\text { في مادة الصولفيج العربي. }
$$

ومن خلا ما سبق نم التحقق من فرض البحث أن التدريبات الصولفائية المستلهمة من المقدمة

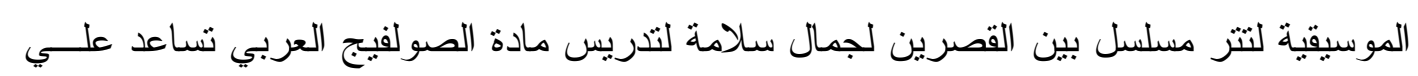
رفع مستوي أداء طلاب الفرقة الأولي بقسم التربية الموسيقية لطلاب كليات التربية النوعية. 


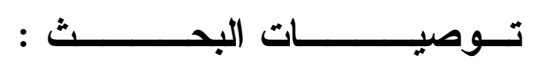

1- التعرف علي طرق جديدة ومبتكرة للمساعدة في رفع مسنوي الأداء في مادة الــصولفيج

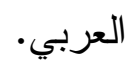

r-يوصي الباحث باستتباط تمارين مستوحاه من بعض ألحان الأغاني المصرية المشهورة

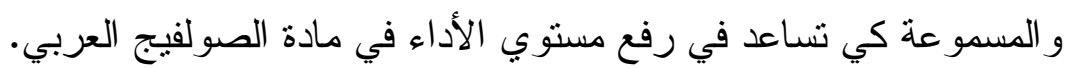
r- تعميم هذه الطريقة المقترحة علي باقي الفرق الثانية و الثالثة و الر ابعة مع استخدام بـاقي لـاقي المقامات الأساسية في الموسيقي العربية من خلال الألحان المشهورة. 


\section{قائمة المراجع}

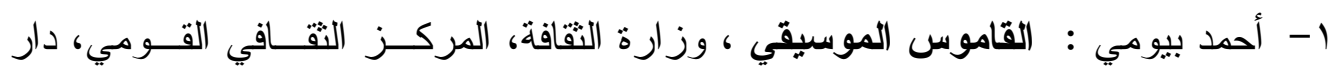

$$
\text { الأوبرا المصرية }
$$

ץ- المعجم الوجيز : مجمع اللغة العربية، القاهرة، .9191 م. م.

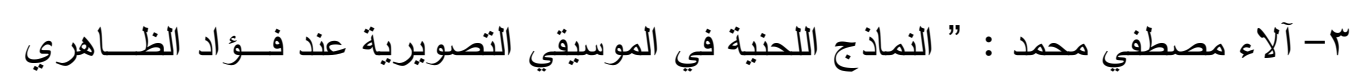

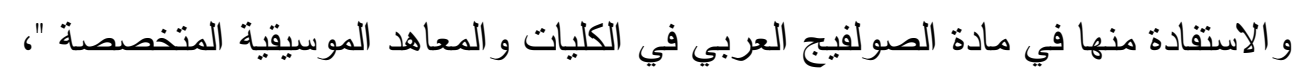

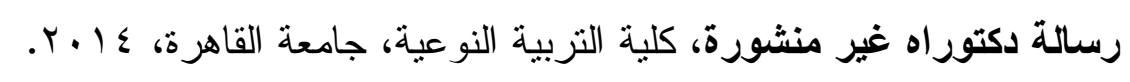

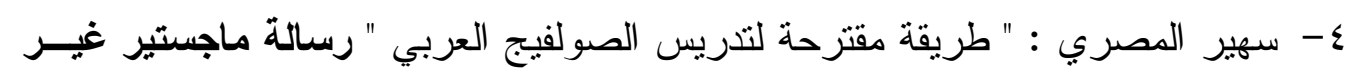

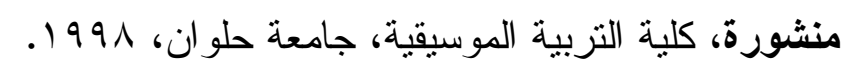
0-سهير عبد العظيم محمد : أجندة الموسيقي العربية، دار الكتب القومية.

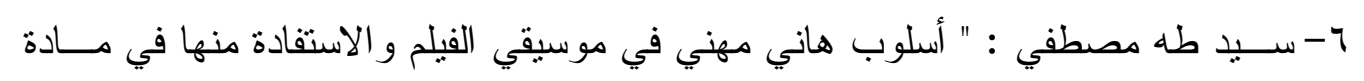

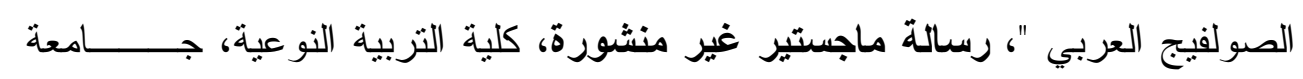

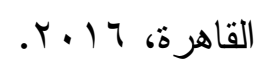

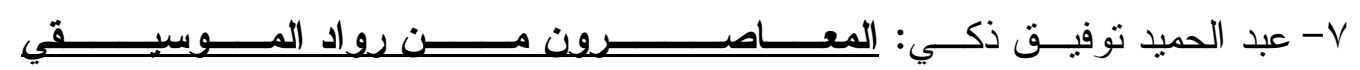

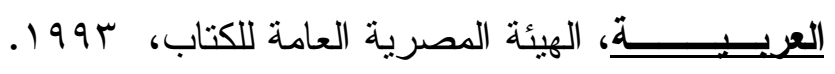

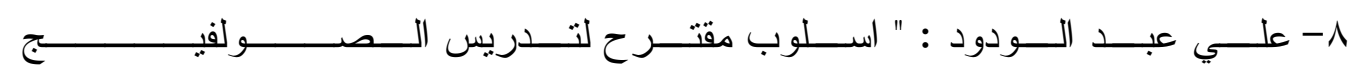

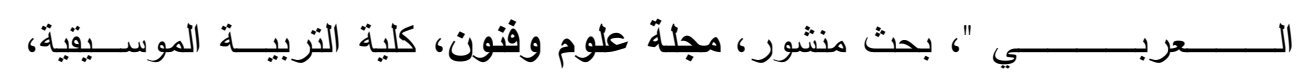

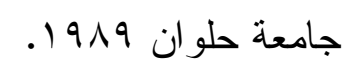

9 - محدد الثربيني محمد : أفقاق السينما ــ في الادراما التلفيزيونية، الهيئة العامة لقصور

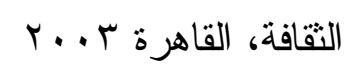

• - - نبيل عبد الهادي شوري : المقدمة في تذوق وتحليل الموسيقي العربية، مصر للخدمات العلمية، القاهرة، 1990.

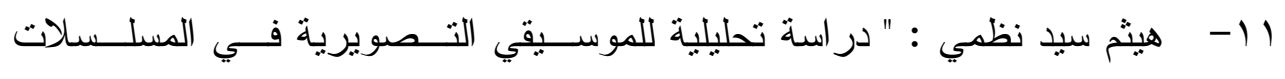

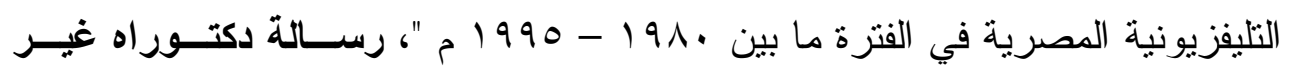

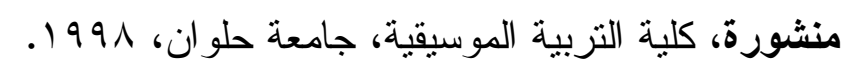




\section{ملخص البحث}

\section{التتر الموسيقي لمقدمة مسلسل بين القصرين لجمال سلامة}

أ.م.د / أسامه سمير عياد

و الاستفادة منه في استلهام تمارين صولفائية لرفع مستوي الأداء في مادة الصولفيج العربي ويهذف هذا البحث الي الاستفادة من المقدمة الموسيقية لتنز مسلسل بين القصرين لجمال سلامة

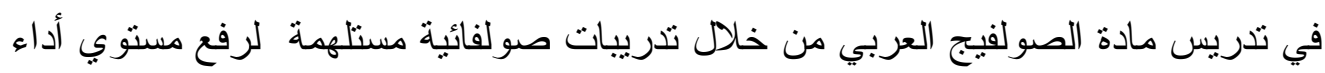
طلاب الفرقة الأولي بقسم التربية الموسيقية لطلاب كليات التربية النوعية. ويشتمل هذا البحث علي جزئين :

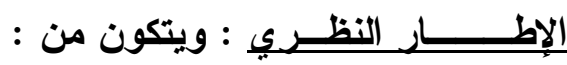
أولاً : نبذة عن حياة جمال سلامة، وجدول يوضح بعض أعماله في مجال الموسيقي التصويرية

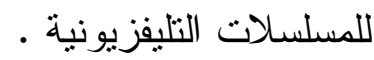

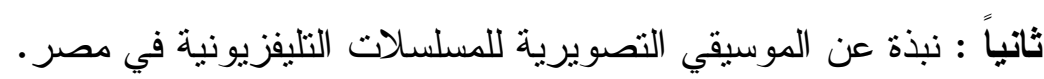

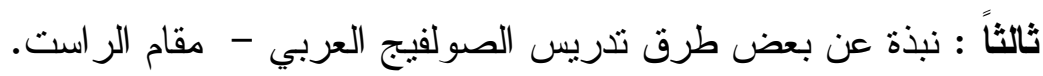

الإططــــــار التطيقي : ويعتمد علي تقسيم تنتر المقدمة الموسيقية لمسلسل بين القصرين لجمال سلامة علي ثلاث أفكار رئيسية، وكل فكرة تحتوي علي ثلاث تمارين مستلامة منها من خلال عدة جلسات.

\section{ثم اختم الباحث بحثة بعرض النتائج، ثم أوصي بالتوصيات التالية :}

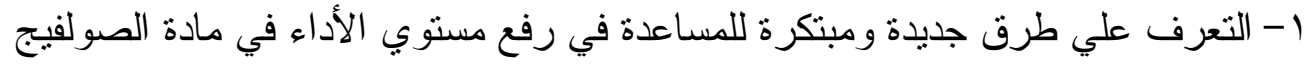

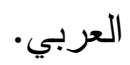

r-يوصي الباحث باستتباط تمارين مستوحاه من بعض ألحان الأغاني المصرية المشهورة

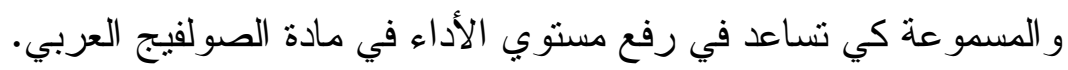

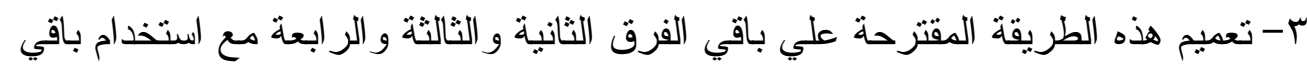

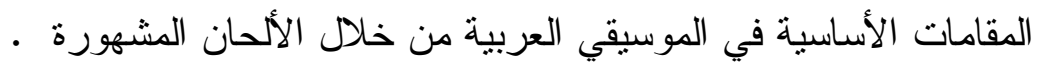

